\title{
Is there a difference in release of high sensitive troponin I and brain natriuretic peptide in acute heart failure with reduced and preserved ejection fraction?
}

\author{
Azra Durak-Nalbantić*, \\ Nafija Serdarević, \\ Alden Begić, \\ Mirza Dilić, \\ Mehmed Kulić, \\ Berina Hasanefendić, \\ Alen Džubur, \\ Aida Hamžić- \\ Mehmedbašić
}

University Clinical Center Sarajevo, Sarajevo, Bosnia and Herzegovina

\section{RECEIVED:}

September 10, 2015

ACCEPTED:

September 17, 2015

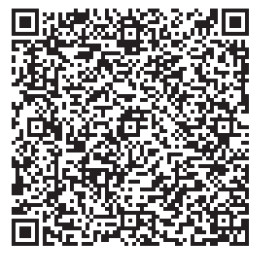

KEYWORDS: brain natriuretic peptide, troponin, acute heart failure
CITATION: Cardiol Croat. 2015;10(9-10):201. | DOI: http://dx.doi.org/10.15836/ccar.2015.201

*ADDRESS FOR CORRESPONDENCE: Azra Durak-Nalbantić, Klinički univerzitetski centar Sarajevo, Bolnička 25, 71000 Sarajevo, Bosnia and Herzegovina. / Phone: +387-61221199 / E-mail: azradurak@yahoo.com

ORCID: Azra Durak-Nalbantić, http://orcid.org/0000-0002-5175-8941 • Nafija Serdarević, http://orcid.org/0000-0001-7977-9819 Alden Begić, http://orcid.org/0000-0002-5374-0892 • Mirza Dilić, http://orcid.org/0000-0002-7309-1455

Mehmed Kulić, http://orcid.org/0000-0003-4864-2013 • Berina Hasanefendić, http://orcid.org/0000-0002-9948-99717 Alen Džubur, http://orcid.org/0000-0003-1198-540X • Aida Hamžić-Mehmedbašić, http://orcid.org/0000-0002-4967-7616

IIIIIIIIIIIIIIIIIIIIIIIIIIIIIIIIIIIIIIIIIIIIIIIIIIIIIIIIIIIIIIIIIIIIIIIIIIIIIIIIIIIIIIIIIIIIIIIIIIIIIIIIIIIIIIIIIIIII

INTRODUCTION: Recently, it has been recognised that up to $50 \%$ of patients with heart failure have preserved ejection fraction. High sensitive troponin I (hs TnI) and brain natriuretic peptide (BNP) are elevated in acute heart failure (AHF) ${ }^{1-3}$ The aim of this study was to investigate possible differences in their release in subpopulation with reduced ejection fraction (HF-REF) in comparison to preserved ejection fraction (HF-PEF) subpopulation.

PATIENTS AND METHODS: we analyzed data from 42 patients hospitalised with AHF in Intensive Care Unit, 2 patients were excluded due to intrahospital death within 72 hours from admission. hs TnI was tested at the admission, while BNP was tested at admission (BNP1) and at discharge (BNP2). We also calculated procentual reduction of BNP at discharge compared to admission values.

RESULTS: 25 patients (62.5\%) had HF-REF with mean LVEF $31.48+/-4.77 \% .15$ patients (37.5\%) had HFPEF with mean LVEF $52.25+/-2.35 \%$. There was no significant difference in hs TnI release according to different systolic function- in HF-REF group mean values was $151.91 \mathrm{pg} / \mathrm{ml}$ vs $60.37 \mathrm{pg} / \mathrm{ml}$ in HF-PEF group ( $\mathrm{p}=0.1$. BNP1 mean values were higher in HF-REF group compared to HF-PEF group-2183.43 pg/ $\mathrm{ml}$ versus $853.96 \mathrm{pg} / \mathrm{ml}, \mathrm{p}<0.05$. Discharge mean BNP values (BNP2) were also higher in HF-REF group compared to HF-PEF-890.30 pg/ml versus $358.03 \mathrm{pg} / \mathrm{ml}, \mathrm{p}<0.05$. There was no significant difference in in-hospital procentual reduction of BNP values (admission vs discharged values) in HF-REF and HFPEF group- $55.72 \%$ versus $55.56 \%(\mathrm{p}=0.77)$

CONCLUSION: Even with more impaired systolic function, hs troponin I mean values in HF-REF were not higher compared to HF-PEF group. Admission and discharge BNP levels were higher in patients with reduced EF compared to patients with preserved EF. That means that neurohormonal activation is more pronounced in subpopulation of patients with reduced LVEF. Percentage of intrahospital BNP reduction were similar in were similar in both groups.

LITERATURE IIIIIIIIIIIIIIIIIIIIIIIIIIIIIIIIIIIIIIIIIIIIIIIIIIIIIIIIIIIIIIIIIIIIIIIIIIIIIIIIIIIIIIIIIIIIIIIIIIIIIIIIII

1. Omland T, Røsjø H, Giannitsis E, Agewall S. Troponins in heart failure. Clin Chim Acta. 2015;443:78-84. Dol: http://dx.doi.org/10.1016/j.cca.2014.08.016

2. Santhanakrishnan R, Chong JP, Ng TP, Ling LH, Sim D, Leong KT, et al. Growth differentiation factor 15, ST2, high-sensitivity troponin T, and N-terminal pro BNP in HF with preserved vs. reduced ejection fraction. Eur J Heart Fail. 2012;14(12):1338-47. DOI: http://dx.doi.org/10.1093/eurjhf/hfs130

3. van Veldhuisen DJ, Linssen GC, Jaarsma T, van Gilst WH, Hoes AW, Tijssen JG, et al. BNP and prognosis in heart failure patients with preserved and reduced ejection fraction. J Am Coll Cardiol. 2013;61(14):1498-506. DOI: http://dx.doi.org/10.1016/j.jacc.2012.12.044 